\title{
Evaluation of Employee Turnover Rates and Leaving Reasons of Nurses Working in the Intensive Care Units
}

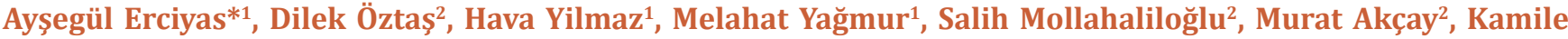 \\ Silay $^{2}$
}

${ }^{1}$ Ankara Atatürk Training and Research Hospital, Turkey

${ }^{2}$ Department of Medicine, Ankara Yildırım Beyazıt University, Turkey

Submission: February 08, 2018; Published: February 26, 2018

*Corresponding author: Ayșegül Erciyas, Ankara Atatürk Training and Research Hospital, Ankara/Turkey, Phone: 90(505)2371318;

Email: aysegul_erciyas@hotmail.com

Abstract

Aim: The current study has been retrospectively carried out due to specify the rotation rate of health care staff worked at intensive care units of Ankara Atatürk Training and Research Hospital between 1st January 2015 and 30th May 2016.

Method: The fully available records of 110 health staff, who worked at the written time, have been searched and the data has been computed by SPSS.

Results: Fifty-four health staff separated from intensive care units during the 17 months period. By calculating with the formula which was used for calculating the work force rotation by managers of human sources, intensive care staff rotation rate has been determined as $50 \%$. Of the separation reasons $35,2 \%$ are pregnancy, delivery permit and continuing unpaid vacation. $57.9 \%$ were between $25-29$ age intervals. Of those $38.1 \%$ reported work overload, $33.3 \%$ negative effect on family life, $19 \%$ stressful working environment, $9.6 \%$ bad work settings.

Conclusion: It is concluded that intensive care rotation rate is high at the hospital. Mostly the pregnancy and continuing unpaid vacations increase the rotation rate.

Keywords: Staff turnover rate; Intensive care unit; Nursing

\section{Introduction}

Employee turnover rate is stated as "the ratio of people who leave their job to the people who are working, in a certain period in a company" or as "entry or exit move into the work force of a company within a certain period". Human resources managers usually use the below formula to calculate the employee turnover rate [1]. The formula is as follows:

Employee Turnover Rate $=\frac{\text { Leaves }}{\text { Average number of workers during the period }} * 100$

Number of Workers at the Start Avg. Number of Employees $=\frac{+ \text { Number of Workers at the End }}{2}$

The factors affecting employee turnover have been defined as personal factors, organizational factors, and economic factors. Personal factors include age, gender, educational level, marital status, working time and experience, work satisfaction, and stress. Organizational factors include organizational structure and employee policies, size of the organization, salary, manager behavior, success evaluation, promotion, and friendship relations [2]. Economic factors include state of the job market, level of employment, and general salary level [1]. The reasons for employee turnover can vary from one sector to another and from one workplace to another, and even it can vary depending on the class, type, location of the workplace, and most importantly the characteristics of the employees [2].

It is not possible for the companies to benefit from the workers efficiently, find good employees, and retain them in the company for a long time as long as the employee turnover rate remains high. Thus, it is suggested for companies to keep their employee turnover rate at a normal level [3]. A good human resources planning is required to eliminate or decrease the factors that affect employee turnover. In this context, the planning should be as such to not create much loss for the company or the worker. Nursing profession, which has a high employee turnover rate in the medical field, is also an occupational group that historically had a high turnover rate in the world. High turnover rate of nurses 
is an important problem affecting both the quality of patient care and the nurses. At the same time, it also negatively affects the morale and efficiency of other nurses and may cause voluntary or involuntary withdrawal from employment [4].

Resignation of an employee with high work performance is a disadvantageous situation for the organization. Even if a new employee has been replaced, time is needed for the new employee to get used to the work environment and carry out the job at the same pace [5]. The researchers agree that a new employee will cause unfavorable results due to decreased efficiency, low morale of the staff, and decrease in efficiency. Along with negative consequences for the patient and the nurses, there is also agreement on the fact that the services provided are very costly. Especially in societies with limited resources, such as in Turkey, the cost of these negative consequences is higher. Thus, employee turnover rate and reasons of nurses for leaving is a subject that the healthcare and nursing directors should lay particular emphasize on and establish effective strategies. There are also factors affecting employee turnover that develop out of the control of the organization.

Usually there are factors such as retirement, reassignment, pregnancy which generally develop out of the control of the hospitals and nurses, the timing of which cannot be estimated, and which are at the same time difficult to be controlled by the organization. In the case that the employee turnover reaches a critical level in the organization, it is necessary to analyze and reveal the reasons for high employee turnover in order to solve the problem [6]. In the case that the employee turnover reaches a critical level in the organization, it is necessary to analyze and reveal the reasons for high employee turnover in order to solve the problem [7]. High or low turnover rate by any means is closely related to the organizational activities. It continues to be of highest priority in the agenda of administrator nurses. Despite that, there are no data showing the leaving rates and reasons of leaving for nurses in Turkey.

\section{Purpose}

The purpose of the study was to determine the employee turnover rate in the intensive care units between January 2015 and May 2016, to determine the reasons for the turnover rates, to determine the factors that cause the nurses withdraw from their job in the intensive care units, and to evaluate the satisfaction levels of the nurses in the clinic in which they are currently working.

\section{Scope}

The study involves the healthcare staff who worked at and who left Ankara Atatürk Training and Research Hospital Intensive Care Units between January 2015 and May 2016.

\section{Method of the Study}

The data were collected retrospectively by evaluating the nurses who worked at and left Atatürk Training and Research
Hospital intensive care units between January 2015 and May 2016. The nurses who voluntarily changed clinics were contacted and surveyed. The survey includes questions regarding sociodemographic characteristics, reasons for leaving, and their satisfaction with the clinic for which they are currently working. The data were analyzed using SPSS.

\section{Results}

Table 1: Socio-Demographic Characteristics of Healthcare Staff Who Left the Intensive Care Unit between January 2015 and May 2016.

\begin{tabular}{|c|c|c|}
\hline Socio-Demographic Characteristics & Number & $\%$ \\
\hline $\begin{array}{c}\text { Gender } \\
\text { Female } \\
\text { Male }\end{array}$ & $\begin{array}{c}51 \\
3\end{array}$ & $\begin{array}{c}94.4 \\
5.6\end{array}$ \\
\hline $\begin{array}{c}\text { Age } \\
18-24 \\
25-29 \\
30-34 \\
35 \text { and above }\end{array}$ & $\begin{array}{c}13 \\
24 \\
8 \\
9\end{array}$ & $\begin{array}{l}24.1 \\
44.4 \\
14.8 \\
16.7\end{array}$ \\
\hline $\begin{array}{c}\text { Level of Education } \\
\text { High School } \\
\text { Associate } \\
\text { Graduate }\end{array}$ & $\begin{array}{l}13 \\
12 \\
29\end{array}$ & $\begin{array}{l}24.1 \\
22.2 \\
53.7\end{array}$ \\
\hline $\begin{array}{c}\text { Years of Work } \\
\text { 0-2 } \\
\text { 03-May } \\
\text { 06-Sep } \\
10 \text { and above }\end{array}$ & $\begin{array}{c}14 \\
13 \\
20 \\
7\end{array}$ & $\begin{array}{r}26 \\
24.1 \\
37 \\
12.9\end{array}$ \\
\hline $\begin{array}{l}\text { Years Worked in the Intensive Care } \\
\text { Unit } \\
0-1 \text { years } \\
2-5 \text { years } \\
6 \text { and above }\end{array}$ & $\begin{array}{c}17 \\
30 \\
7\end{array}$ & $\begin{array}{c}31.5 \\
55.5 \\
13\end{array}$ \\
\hline TOTAL & 54 & 100 \\
\hline
\end{tabular}

Atatürk Training and Research Hospital has a total of 488 beds and the intensive care units have 67 beds of 507 nurses actively working in the hospital, 110 have been employed in the intensive care units. The mean age of the staff working in the intensive care unit is 30.3 , the mean working time in the occupation is 7.7 years; in terms of educational level; $3.7 \%$ have a postgraduate degree, $52.7 \%$ have an undergraduate degree, $21.8 \%$ have an associate degree, and $21.8 \%$ have a high school degree. A total of 54 healthcare staff has left the intensive care unit between January 2015 and May 2016. 53.7\% of the staff who left had a graduate degree, $44.4 \%$ was between the ages of $25-29$, $24.1 \%$ had been doing this job between $3-5$ years, and $55.5 \%$ had a working duration of 2-5 years in the intensive care unit. Their socio-demographic characteristics are presented in the Table 1. 
When calculated according to the formula used by the human resources directors to calculate employee turnover rate, it is seen that the intensive care employee turnover rate was $50 \%$ in the 17-month study period.
The reason for job withdrawal was pregnancy and maternity leave with subsequent unpaid leave in $35.2 \%$ of the employees, whereas $29.6 \%$ changed their ward due to various reasons. The factors that cause the healthcare staff to leave the intensive care unit are presented in the Figure 1.

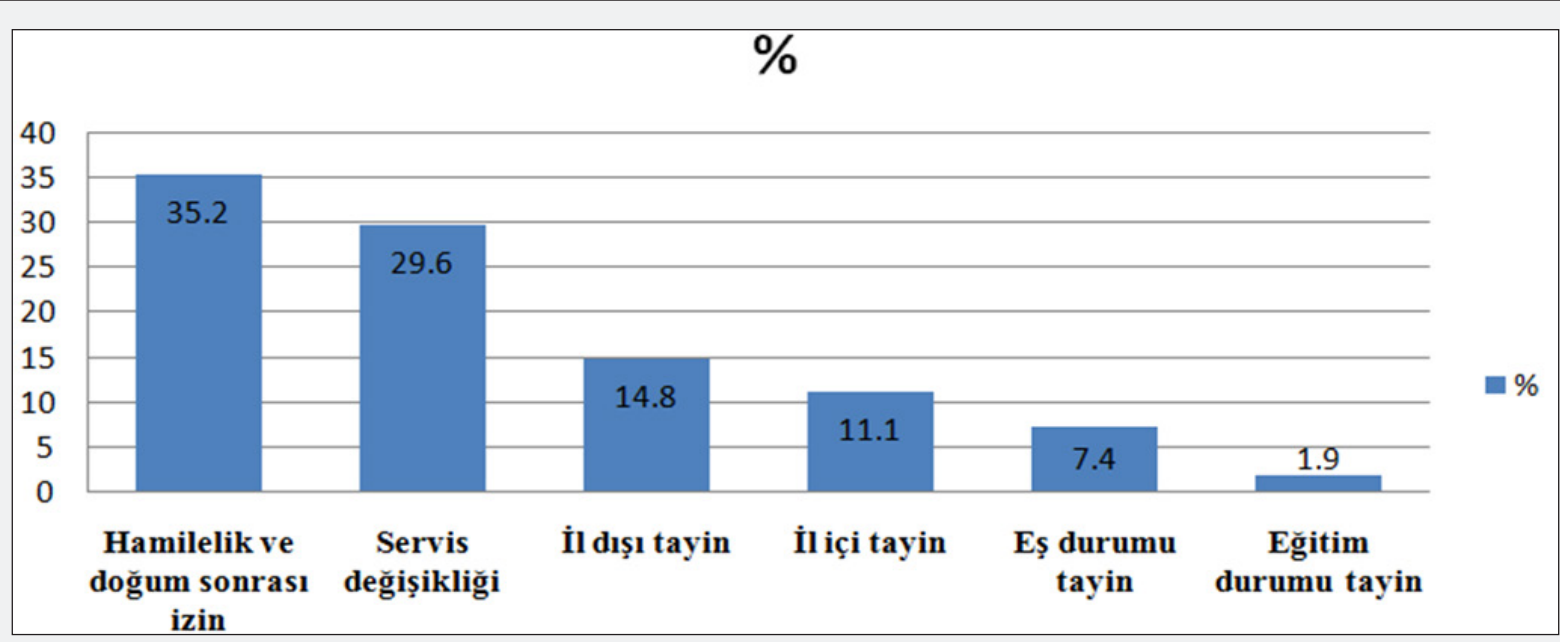

Figure 1: Factors Causing Healthcare Staff to Leave Intensive Care Unit.

Hamilelik ve doğum sonrası izin: Pregnancy and maternity leave,

Servis değişikliği: Change of ward

İl dişı tayin: Re-assignment outside of the city

İl içi tayin: Re-assignment within the city

Eş durumu tayin: Spouse-related re-assignment

Eğitim durumu tayin: Re-assignment according to educational status
Of healthcare staff that voluntarily changed departments or hospitals, $76.2 \%$ were between the ages of 21 and 30 years, $52.4 \%$ were single, $47.7 \%$ had a graduate degree, and $47.6 \%$ had provided service in the intensive care unit for the duration of 1-5 years. Their socio-demographic characteristics are presented in the Table 2. The reason for requesting department change was high workload of the intensive care unit in $38.1 \%$, negative effects on their family lives in $33.3 \%$, stressful working environment in $19 \%$, and poor working conditions in $9.6 \%$ of the nurses Figure 2.

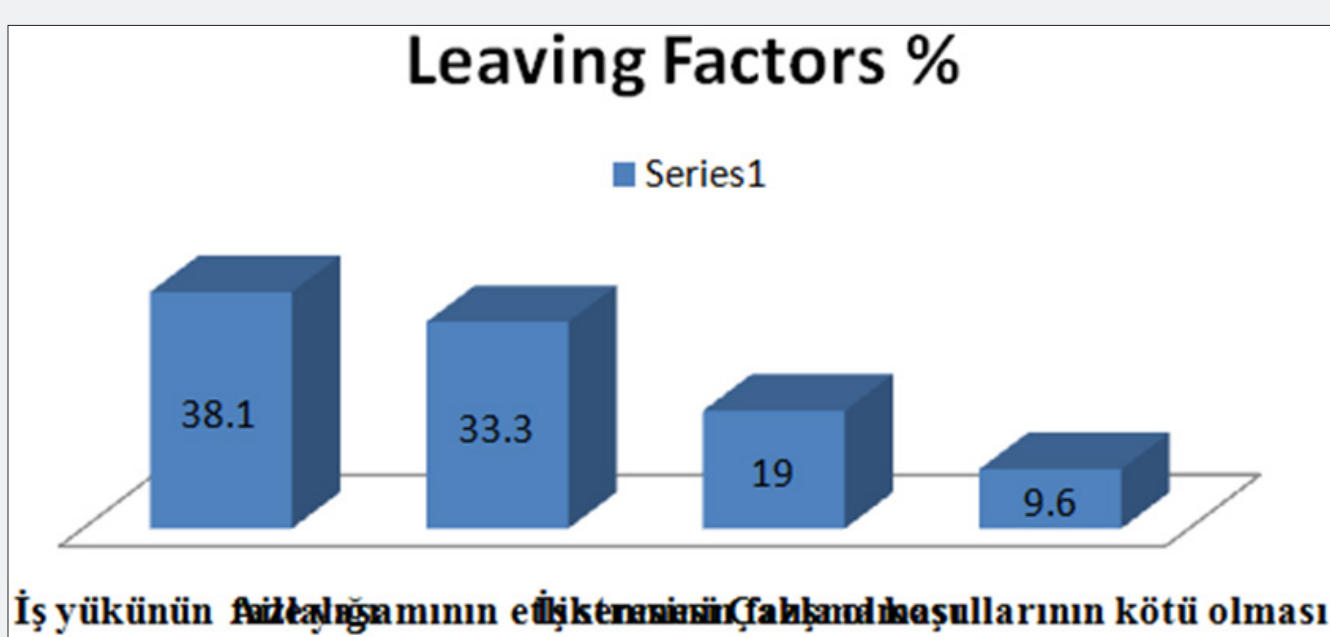

Figure 2: Leaving Reasons of the Healthcare Staff Who Left the Intensive Care Unit.

Seri 1: Series 1, İş yükünün fazlalığı: High workload

Aile yaşamının etkilenmesi: Affected family life
İş stresinin fazla olması: High work stress

Çalışma koşullarının kötü olması: Poor working conditions 
Table 2: Socio-Demographic Characteristics of the Healthcare Staff who Left the Intensive Care Unit.

\begin{tabular}{|c|c|c|}
\hline $\begin{array}{l}\text { Socio-Demographic } \\
\text { Characteristics }\end{array}$ & Number & $\%$ \\
\hline $\begin{array}{c}\text { Age } \\
21-30 \\
31-40\end{array}$ & $\begin{array}{c}16 \\
5\end{array}$ & $\begin{array}{l}76.2 \\
23.8\end{array}$ \\
\hline $\begin{array}{c}\text { Marital Status } \\
\text { Married } \\
\text { Single }\end{array}$ & $\begin{array}{l}10 \\
11\end{array}$ & $\begin{array}{l}47.6 \\
52.4\end{array}$ \\
\hline $\begin{array}{c}\text { Education Level } \\
\text { High School } \\
\text { Associate } \\
\text { Graduate }\end{array}$ & $\begin{array}{c}4 \\
7 \\
10\end{array}$ & $\begin{array}{c}19 \\
33.3 \\
47.7\end{array}$ \\
\hline $\begin{array}{c}\text { Years Worked in the } \\
\text { Intensive Care Unit } \\
\text { 01-May } \\
06-\text { - } \\
\text { Nov-20 } \\
21-30 \text { and above }\end{array}$ & $\begin{array}{l}10 \\
7 \\
3 \\
1\end{array}$ & $\begin{array}{r}47.6 \\
33.3 \\
14.3 \\
4.8\end{array}$ \\
\hline Total & 21 & 100 \\
\hline
\end{tabular}

The healthcare personnel who have been voluntarily transferred to another clinic were asked whether they were satisfied with their current working environment and 52.4\% reported satisfaction with their clinic (Table 3).

Table 3: Satisfaction Status of the Healthcare Staff Who Left the Intensive Care Unit with their current workplace.

\begin{tabular}{|c|c|c|}
\hline Satisfaction Status & Number & \% \\
\hline Very satisfied & 4 & 19 \\
\hline Satisfied & 11 & 52.4 \\
\hline A little satisfied & 5 & 23.8 \\
\hline Not satisfied at all & 1 & 4.8 \\
\hline TOTAL & 21 & 100 \\
\hline
\end{tabular}

\section{Discussion}

In this study where the turnover rates of the healthcare staff working in the Atatürk Training and Research Hospital Intensive care units were analyzed, turnover rate profiles between January 2015 and May 2016 were determined. Approximately 108 out of 507 actively working nurses in the hospital have been employed in the intensive care units. The mean age of the staff working in the intensive care unit is 30.3 , the mean working time in the occupation is 7.7 years, and $52.7 \%$ have graduate degree. During a total of 17 months period, 54 healthcare personnel have left the intensive care unit. When calculated according to the formula used by the human resources directors to calculate employee turnover rate, it can be seen that the intensive care employee turnover rate is $50 \%$. According to the classification in the study carried out abroad regarding the level of nurse turnover rate; a turnover rate between $4 \%$ and $12 \%$ is considered to be low, a rate of $12-22 \%$ is considered to be medium, and a rate of $22-44 \%$ is considered to be high [8].

When the employee turnover rate reaches $50 \%$, it affects productivity and other staff negatively $[9,10]$. It can be said that the turnover rate in our study is high. In another study, turnover rate of intensive care unit nurses was found to be $64.6 \%$, a finding indicating a high turnover rate, and it was thought that high turnover rate reported in this study may have been caused by the fact that the study was conducted by the nurses [11]. However, turnover rates of nurses in Norway and other European studies have exceeded the results reported by Leite et al. [11,12].In a study, it was detected that high turnover rate of nurses shows that emotional burnout is increasing amongst the intensive care employees and that the communication bonds between the nurses are decreasing. In a meta-analysis study, low work satisfaction and low institutional loyalty are amongst the factors that affect turnover rate of nurses [14,15].

In our study, it can be seen that the reason for leaving for $35.2 \%$ of the healthcare staff working in intensive care units is unpaid leave following pregnancy and maternity leave and $57.0 \%$ of them are between the ages of $25-29.44 .4 \%$ of the 54 intensive care staff who left is also in this age group. According to the data of Turkish statistical institute, it was reported that individuals aged 25-29 years represent the fertility age group [16]. Considering the fact that healthcare staff working in the intensive care units should have a certain amount of knowledge and experience and be in the 25-30 years age range when their physical strength and endurance is at the highest level, it can be said that there is a loss of workforce. Individuals leaving workplace for reasons other than pregnancy leave, relocation out of city, educational reasons and spouse-related relocation account for $29.6 \%$ of the turnover rate. Environmental factors, geographical factors such as a job opportunity outside of the organization can affect the turnover rate [9].

Amongst the healthcare employees who had their departments changed or who changed hospitals as per their own request, $76.2 \%$ were between the ages of $21-30,52.4 \%$ were single, $47.7 \%$ had graduate degree, $47.6 \%$ worked at the intensive care unit between $1-5$ years. $38.1 \%$ of these stated too much workload as the reason, $33.3 \%$ stated that their family life is being negatively affected, $19 \%$ stated that the work environment is stressful, and $9.6 \%$ stated that working conditions are poor. When the satisfaction states of the 21 people who had their department or hospital changed are considered, it was detected that $19 \%$ are very satisfied, $52.4 \%$ are satisfied, and $4.8 \%$ are not satisfied at all with the units they are currently working. In a study, it was reported that the authors thought that turnover rate increases related to the nurses having too many working hours, having too many night shifts, not being compensated for the extra work, and not being able to take leaves [17]. 


\section{Conclusion}

In conclusion, it can be seen that the turnover rate is increased mostly by the unpaid leaves taken after the pregnancy and the following period. Employees who have left voluntarily have stated the reason of excessive workload as another factor and it was detected that the employees who were shifted to another place were satisfied with their new place. It was concluded that the intensive care turnover rate in the hospital is high.

\section{References}

1. Yilmaz B, Halici A, (2010) İşücü Devir Hızını Etkileyen Etmenler: Sekreterlik Mesleğinde Bir Araştırma. International Journal of Economic and Administrative Studies Year 2(4): 93-108.

2. Demir M (2002) Konaklama İșletmelerinde İnsan Kaynakları Kapsamında İșgücü Devir Hızının Analizi; Muğla Bölgesi Örneği. Yüksek Lisans Tezi. Dokuz Eylül Üniversitesi Sosyal Bilimler Enstitüsü, İzmir.

3. Tütüncü Ö, Demir M (2003) Konaklama İșletmelerinde İnsan Kaynakları Kapsamında İşgücü devir Hızının Analizi ve Muğla Bölgesi Örneği. Dokuz Eylül Üniversitesi Sosyal Bilimler Enstitüsü Dergisi 5(2): 146-169.

4. Cavanagh SJ, Coffin DA (1992) Staff turnover among hospital nurses. Journal of Advanced Nursing 17(11): 1369-1376.

5. Gray AM, Phillips VL, Normand C (1996) The costs of nursing turnover: evidence from the British National Health Service. Health Policy 38(2): 117-128.

6. Sürer P (2009) Hastanede Çalışan Hemşirelerde İşgücü Devir Hızıve Ayrılma Nedenlerinin İncelenmesi Pınar Sürer Hemşirelikte Yönetim
Anabilim Dalı Yüksek Lisans Tezi İzmir. Dokuz Eylül Üniversitesi Sağlık Bilimleri Enstitüsü.

7. Şimşek MŞ, Çelik A, Akgemci T (2001) Davranış Bilimlerine Giriş ve Örgütlerde Davranış, Nobel Yayın Dağıtım, Baskı, Ankara, pp. 353.

8. http://www.healthleadersmedia.com/content/132674.pdf.

9. Price J, Mueller C (1981) Professional Turnover: The Case for Nurses. Iowa State University Press, Ames. Health Syst Manage 15: 1-160.

10. Mueller CW, Wallace JE, Price JE (1992) Employee Commitment: Resolving Some Issues. Work and Occupations 19(3): 211-236.

11. Leiter MP, Maslach C (2009) Nurse turnover: the mediating role of burn out. J Nurs Manag 17(3): 331-339.

12. Jourdain G, Chenevert D (2010) Job Demands-resources, burn out and intention to leave the nursing profession: A questionnaire survey. Int J Nurs Stud 47(6): 709-722.

13. Myhren H, Ekeberk O, Stokland O (2013) Job satisfaction and burn out among intensive care unit nurses and physicians. Crit Care Res Pract 2013: 786176.

14. Mosallam R, Hamidi S, Elrefaay M (2015) Turn over Intention among intensive care unit nurses in Alexandria, Egypt. Journal of the Egyption Public Health Association 90(2): 46-51.

15. Yin JC, Yang KP (2002) Nursing Turn over in Taiwan: a meta-analysis of related factors. Int Nurs Stud 39(6): 573-581.

16. http://www.tuik.gov.tr/PreHaberBultenleri.do?id=21514.

17. Kocaman G, Seren Ş, Kurt S, Danifi B, Erer T (2010) Üç Üniversite Hastanesinde Hemflire Devir Hızı. Turnover Among Nurses at Three University Hospitals Hemşirelikte Eğitim ve Araștırma Dergisi 7(1): 34-38.
Your next submission with Juniper Publishers will reach you the below assets

- Quality Editorial service

- Swift Peer Review

- Reprints availability

- E-prints Service

- Manuscript Podcast for convenient understanding

- Global attainment for your research

- Manuscript accessibility in different formats ( Pdf, E-pub, Full Text, Audio)

- Unceasing customer service

Track the below URL for one-step submission https://juniperpublishers.com/online-submission.php 